\title{
シールドトンネルセグメント継手部の 局部応力性状
}

\author{
今田徹 ${ }^{1} \cdot$ 山崎良一 $^{2} \cdot$ 野本寿 $^{3} \cdot$ 三戸憲二 $^{4} \cdot$ 山崎宏 $^{5}$
}

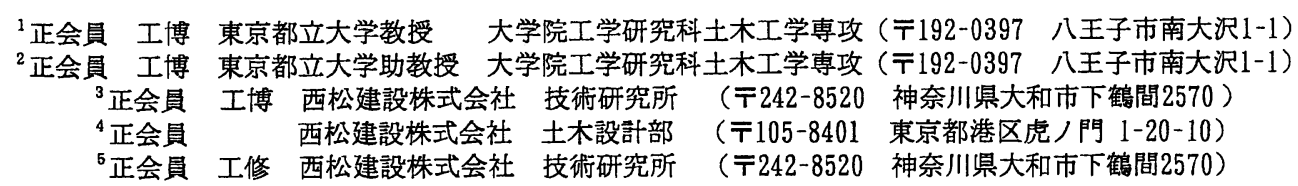

シールドトンネルのセグメント形式は多様であるが, その殆どは, セグメント端部を染き合わせボルト あるいはほぞなどで力を伝達する形式となっている.この突き合わせ部で曲げ, 軸力, せん断力の伝達が 行われることになるが,これらは接触面を介して行われることになり, 接触問題として局部的に非常に複 雑な応力状態になる. 本論文は, 矩形, 台形, 凸型などのコンクリートセグメントで採用される単純突き 合わせ，ほぞなどの基本的な継手構造に関し，軸力，曲げ，せん断を受けたときの局部応力の状況を光弾 性実験により検討を行ったものである，その結果，応力の伝達が円滑に行われる場合もあるが，状況によ り大きな応力集中が生するここと明らかにした.

Key Words : shield, segment lining, segment joint, rectangle segment, trapezoid segment, convex segment, photoelasticity

\section{1. 緒言}

シールドトンネルの覆工は，セグメントと呼ばれ る分割された構造要素を組み立てて作られる. その ため, 継手が必要となり，組み上げられて一体とな った覆工の力学的な挙動は, 継手の特性によって支 配される.また, 継手の形式によっていろいろな形 式のセグメントが使用されている. 通常, セグメン トの検討はセグメントをマクロにとらえて梁とし， 継手部は剛性低下を表現できるバネとしている．し かし, 継手構造は基本的には突き合わせ構造であり, 面と面とが接触する構造になっている．このことは， 継手の挙動は基本的構造である継ぎボルトなどの継 手の構成, 継手面の形状などの他, 面の仕上がりの 程度の影響を受ける接触問題を含むことになる. ま た，最近は六角セグメント継手 ${ }^{11}$ ，2)，凸型セグメ ント ${ }^{3)}$.4) 等にみられるように, 複雑な形状を有す る継手が開発されてきている。これらの継手では, セグメントを単に梁と見なすだけでは十分でなく， 継手形状の変化に伴う局部的な応力集中が問題とな ることが考えられる. 応力の集中は局部的なひび割 れの発生や欠けの原因となることになるので，セグ メントの設計においてはできるだけ局部的な応力の
集中を避けなければならない，光弾性実験法は応力 の伝達状況を縞模様で表現できるので, 全体の応力 分布や応力集中が形状によってどのように変化する かを見るのに適している，そこで，光弾性実験法を 用いセグメントの継手部に生じる応力集中之応力伝 達に関する問題を検討した.

ここで取り上げたセグメントの形状は，平面的形 状が長方形となっている矩形セグメント ${ }^{51}$, 形状が 台形亡なっている台形セグメント $\left.{ }^{61} ， 71 ， 8\right)$, 台形の 変形として筆者らが開発を進めている凸型セグメン ト（図ー1 1 参照) 3)，4)の 3 種類である.

セグメントの継手面は，フラットであるものと面 に半円の凹凸を設けたものとがある.凹凸継手構造 は, リング間継手構造に用いられており，この継手 構造はピンホゾ継手と呼称されている。このことか ら筆者らも，凹凸継手構造をピン・ホゾ継手之呼称 していた，一方，木材・石材・鉄材など二つの部材 を接合するときの突起を「ほぞ」，突起をはめこむ 穴を「ほぞあな」と称することから，これにちなん で「ほぞ付きセグメント」などの呼称も散見する ${ }^{{ }^{9}}$. そこで筆者らも，従来の言葉を取り入れた一般性の ある表現として, 以下この形式の継手を「ほぞ形式 継手」と呼称することにする. 
すでに筆者らは, 光弾性応力凍結法による矩形セ グメント継手リングによる実験的研究を行った ${ }^{5}$. また，それに継続して，台形セグメントリングによ る実験も実施した ${ }^{7)}$ 。これらの実験の結果によれば, 継手の挙動はマクロにはそれぞれの継手の形状など, 構造的な特性に支配されるが，ほぞ形式の継手では， 局部的な応力集中が発生し, 継手部の応力が複雑 と なる.これらのことから，継手部については十分な 検討が必要であることが示唆された.

そこで，(a) 台形セグメント，六角セグメントな ど, トンネル軸方向と斜めの角度を持つ突き合わせ セグメント継手部の応力性状（セグメント間の応力

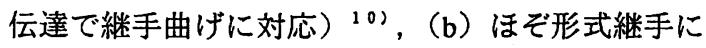
おける突き合わせ部の応力性状（セグメント間の応 力伝達で円周方向軸力が作用する場合） 111，12)，

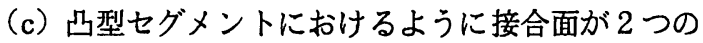
平面からなるセグメントの交角における継手の応力 性状 (リング間の応力伝達でトンネル方向推力が作 用する場合） ${ }^{15)}$ および(d）せん断キ一を有する継 手の局部応力性状（セグメント間およびリング間の 応力伝達でトンネルの半径方向から外力が作用する 場合） ${ }^{17}$ に関する光弾性実験を実施した.

以上，シールドトンネル覆エセグメント継手部の 光弾性実験により, 視覚的ではあるが, 継手部の応 力性状を明らかにすることができたので報告する．

なお，この実験に使用した光弾性材料は，アラル ダイト B (CT 200) と硬化剂 HT 901 を 100 対 30 の 割合で混合した高温硬化エポキシ樹脂である.

\section{2.トンネル軸方向と斜めの角度を持つ突き} 合わせセグメント継手部の応力性状 101

実物モデルによる平板継手曲げ試験では，継ぎボ ルトで両セグメントを接続することから，そのまま の形で曲げ試験を行うことができる.これに対し， 継ぎボルトを用いない場合は載荷治具を用い，さら に梁モデルの長さ方向に軸力を必要とする. このこ とから, 実物平板曲げ試験とは少し異なったものと なるが，継手部の応力伝達を見る一つの方法之考え， 以下の実験を行うことにした.

図ー 1 は，エポキシ樹脂製のセグメント試験片で ある. 図ー 2 に示す治具に, 同一角度を持つ一対の 試験片 2 枚を㨂入し, 純曲げ載荷状態で応力凍結を 行った.

純曲げ載荷実験を行うために用いた治具は, 試験 片と同一の線膨脹係数を持つエポキシ樹脂である. これを用いるもことにより, 治具とモテルは温度に 対して一体となって挙動する. 実験状態は三層の重

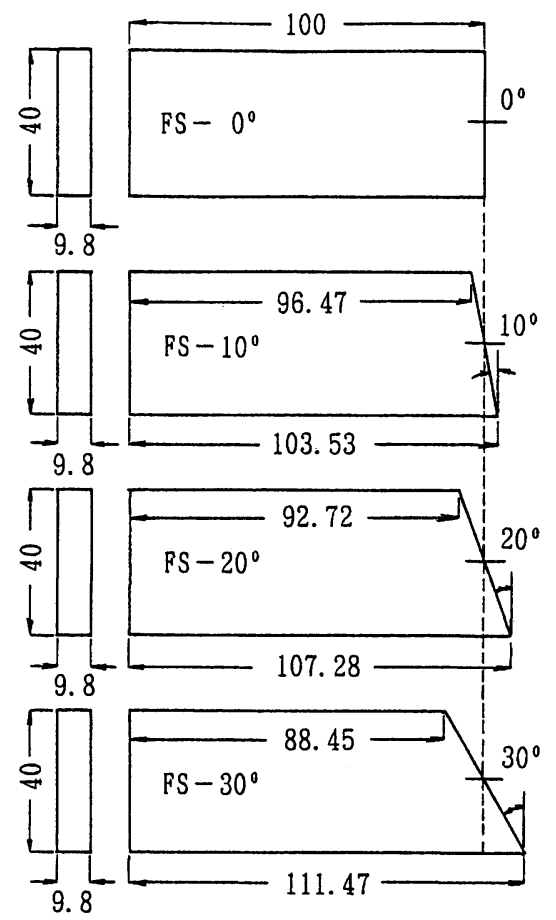

図ー 1 実験モデ
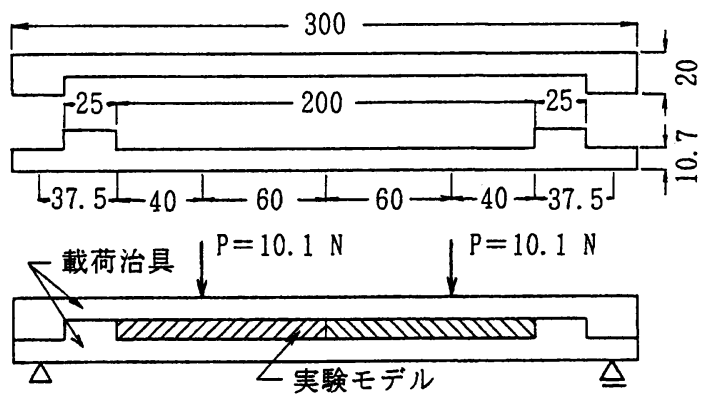

図ー2 載荷治具と純曲げ載荷

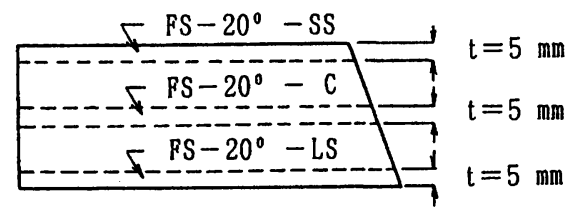

図一３スライスの採取位㯰

ね梁であるが, 試験片は下部治具に設けた突起の間 に挿入されるので, 軸方向へのずれは拘束される. このため，下部治具と試験片は一体となり，上部治 具と試験片とは重ね梁的な挙動を示すことになる.

モデルの接触応力を見るためには，接触断面に対 して垂直な方向のスライスを採取するのがよいが, 


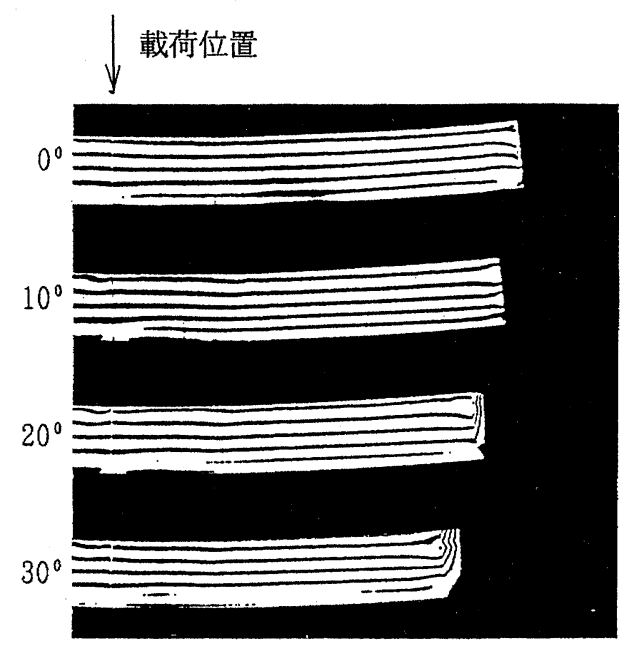

(a)

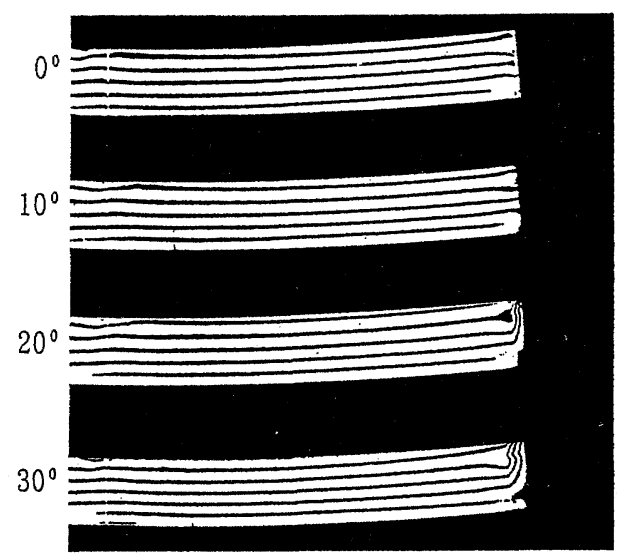

(b)

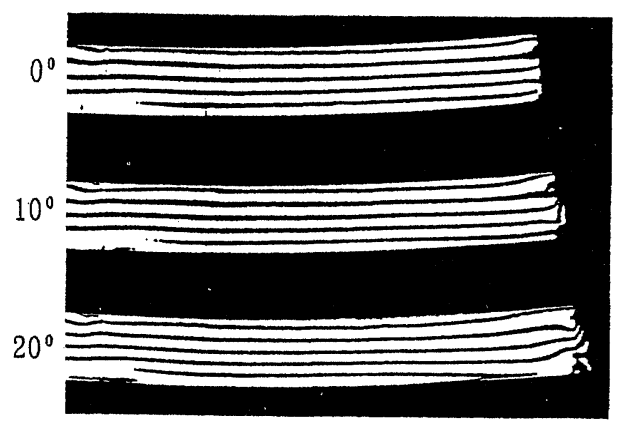

(c)

図-4 等色線写真

接触位置からの影響範囲を調べるには円周軸方向の スライスを採取した方がよい，図ー3にスライスの 採取位置を示す。

スライスは短い辺(SS) と長い辺(LS)および両者 の中心 (C)を含む, 厚さ $5 \mathrm{~mm}$ の短冊を採取した.

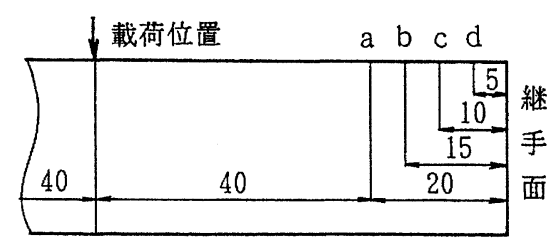

（FS- $0^{0}$-SS の寸法表示例 )
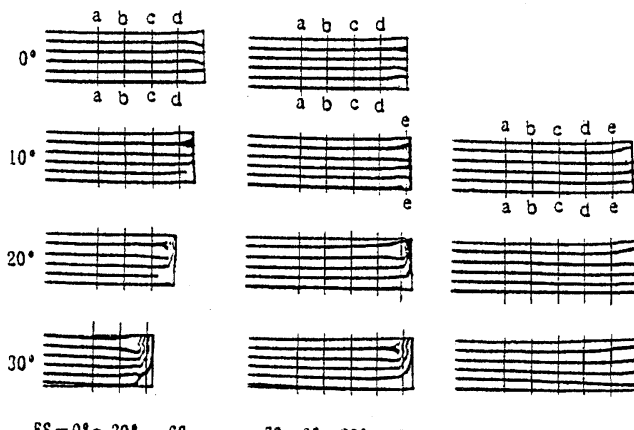

$f S-0^{\circ} \sim 30^{\circ}-S S$

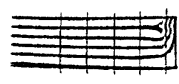

FS $-0^{\circ} \sim 30^{\circ}-6$

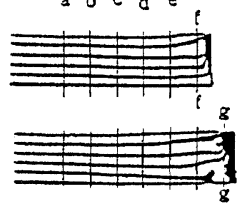

$8 S-10^{\circ} \sim 30^{\circ}-L S$

図ー5 モテル継手面からの影響範囲

これらの記号として，例えば，突き合わせ角度が $20^{\circ}$ の場合, 短い辺から順次 FS-20 -SS, FS- $20^{\circ}-\mathrm{C}$, FS- $20^{\circ}$-LS を用いることにする.

図一 4 は，かくして得られた等色線写真（暗視野 : 縞次数が $0,1,2,3, \cdots \cdots)$ である. 図-4(a) のグループは短い辺，(b)グループは中央，(c)グル 一プは長い辺の実験結果である. 突き合わせ角度の 違いによる比較を容易にするために，図一 2 に示し た載荷位置（左）を基準とした写真としている．ま た，図一 4 において，突き合わせ角度が $0^{\circ}$ の場合 を除き，継手面近傍の縞が乱れているのは，この位 置のスライスの形状が契になっているからである.

図- 5 (等色線写真の 明視野: 縞次数が $0.5,1.5$, $2.5, \cdot ・)$ は，モデル継手面からの影響範囲を梁 幅との関係で示したものである。図の左上に揭げた 長方形モデル( FS-0 $0^{\circ}$-SS )において，載荷位置から 計って a 位置までの距離が梁幅 $(4 \mathrm{~cm})$ ，接手面か らは梁幅の 0.5 に当たる $2 \mathrm{~cm}$ である．以下，b， $\mathrm{c}, \mathrm{d}$ は接手面から梁幅の $0.375,0.25,0.125$ に当た る $1.5 \mathrm{~cm}, 1.0 \mathrm{~cm}, 0.5 \mathrm{~cm}$ となっている. 角度を有 するモデルも同様である.

図ー 5 によれば，モデル接手面からの影響範囲は， 角度 $0^{\circ}$ の場合が最も小さく，梁幅の 0.125 に当た る $0.5 \mathrm{~cm}$ 程度である. 一方，大きいのは角度が $30^{\circ}$ の場合の長辺側（LS）で，ここでは梁幅の 0.7 に当たる $2.8 \mathrm{~cm}$ 程度まで影響が及んでいる.これ らのことから，矩形セグメントでは継手であること 
の影響は小さい範囲にとどまる。これに対し，台形 セグメントの鋭角側では, 継手による影響の範囲が 広くなる。ことに継手角度が大きくなるに連れてそ の影響は顕著になる，等のことが言える。

3.ほぞ形式継手における突き合わせ継手部 の応力性状 '1) , 12)

ほぞ形式継手を有するセグメントリングの実験結 果 ${ }^{5)}$ によれば，ほぞの径が大きくなるに連れて，継 手部の平板部に応力が集中する傾向にある. そこで これら継手部の応力伝達を調查するため，ほぞの径 が継手面上で変化する 6 種類のモデルについて実験 を行った.

図ー6にほぞ形式継手モテルの形状寸法, 表一 1 に実験の種類を示した. 継手面上のほぞの加工は, 半円上のすべてのところで接触し，両者が無理なく はまることを目標にした.

この実験では応力凍結法を用いた. 図ー7に実験 用載荷装置の概略を示す. 装置外枠の大きさは 150 $\times 150 \times 255 \mathrm{~mm}$ である. この中央にモテルを収納 する長方形の箱が取り付けてある. この箱の手前部 分の板は取り外しができるようになっている．また， 中のモデルが見えるように, 上中下の三力所にのぞ き空があけられている.この箱も鉄製で，幅はモデ ルの寸法 $32 \mathrm{~mm}$ に合わせているが, エポキシ樹 脂の線膨脹を考虑し, 応力凍結時に箱側面と接触し ないようなクリアランスは確保している. モテルの 厚さ方向については, モデルセットの段階で, モデ ルは裹側の鉄板に接している。これはクリアランス を持たせたモデルのセットがしにくいのと，厚さ方 向の膨脹は小さく, また偏光の透過方向で光弾性効 果が現れないからでもある.

実験モデルの載荷部は山形に加工してあるが, こ の山形に合わせた治具を用い, 軸方向のみの外力が 伝達するようにした. 載荷は, $\phi 15 \mathrm{~mm}$ の丸鋼が 二カ所のガイド穴を通して鉛直方向に伝達される構 造の載荷治具の荷重受けに実荷重を載せて行うが, このときの載荷点の先端はモテル載荷部に取り付け た治具の穴に入るようになっている.

応力凍結サイクルは, 60 分で $130^{\circ}$ まで温度を上 げ，その温度で 90 分間据え置いた後 1 時間当たり $5^{0} \mathrm{C}$ の割合で徐冷した。 これらは，実験炬に取り付 けられているデジタルプログラム温度計で行ってい るから, 応力凍結に対する温度管理はすへての実験 モデルに対し，同一条件となっている.

図ー8はほぞ形式継手部の等色線写真（明視野）

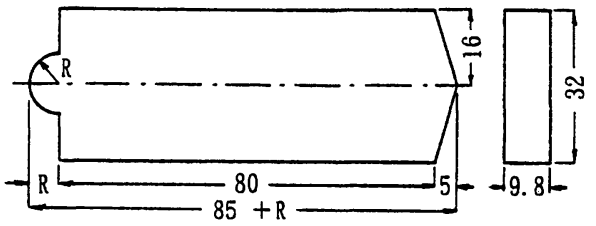

ほぞ側

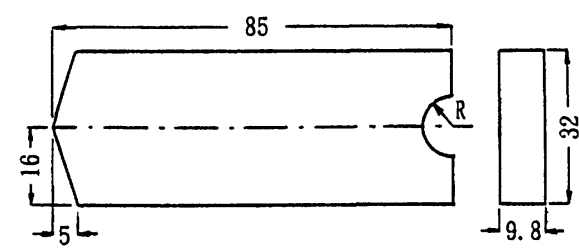

ほぞ溝側

図ー6 ほぞ形式継手モテルの形状寸法

表 -1 実験の種類

\begin{tabular}{|c|c|c|c|}
\hline 記号 & $\begin{array}{c}\text { ほぞの } \\
\text { 直径 } \mathrm{mm}\end{array}$ & $\begin{array}{c}\text { モデルの } \\
\text { 厚さ } \mathrm{mm}\end{array}$ & $\begin{array}{c}\text { 荷 重 } \\
\mathrm{N}\end{array}$ \\
\hline $\mathrm{J}_{\mathrm{A}}-4 \mathrm{R}$ & 8 & 9.8 & 31.4 \\
$\mathrm{~J}_{\mathrm{A}}-6 \mathrm{R}$ & 12 & 9.8 & 31.4 \\
$\mathrm{~J}_{\mathrm{A}}-8 \mathrm{R}$ & 16 & 9.8 & 31.4 \\
$\mathrm{~J}_{\mathrm{A}}-10 \mathrm{R}$ & 20 & 9.8 & 31.4 \\
$\mathrm{~J}_{\mathrm{A}}-12 \mathrm{R}$ & 24 & 9.8 & 31.4 \\
$\mathrm{~J}_{\mathrm{A}}-14 \mathrm{R}$ & 28 & 9.8 & 31.4 \\
\hline
\end{tabular}

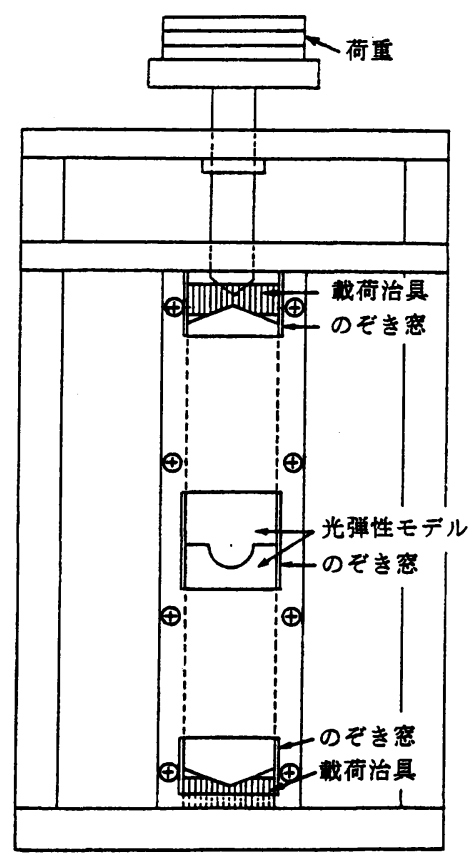

図ー7 ほぞ形式継手実験の載荷概略図 
である. この写真の中で対称性があり, 縞模様も明 瞭な $\mathrm{J}_{\Lambda}-8 \mathrm{R}$ を観察すると, ほぞ溝部の縞模様が, 円孔を持つ帯板の引張試験で現れる縞 ${ }^{13)}$ によく似 ていることが分かる.このことは，この場合の応力 伝達が継手平面で行われ，ほぞでは伝達されていな いことを意味している.これより，ほぞ形式継手の 応力伝達は, ほぞの半径が小さい場合は継手平面で, 大きくなるとほぞおよび継手平面で行われているこ とが推察される. 両者の境目は，ほぞの半径が継手 平面幅の $1 / 2$ を少し越えたところである.

ほぞの径が大きくなるにつれて継手平面積が小さ くなる. その結果, 平面部に応力が集中し, それに よる破損が生じることになる。このことからもほぞ の径は最小必要限の大きさとし, 平面部で応力を伝 達させることが望ましい。

以上は実験結果からの考察であるが，この実験結 果の検証之, 実験資料だけではよく分からない部分 の応力状態を明らかにするため, 近似解析を試みた. その方法は, 光弾性実験結果を参考として有限要素 法による応力解析を行い, 光弾性実験を再現できる 解析条件を見いだすことにより, 継手部の応力伝達 機構を数值解析の面から明らかにするというもので ある. しかし，継手部の接触面は自由周辺ではない から，実験値を定量的に把握することには無理があ る. このことから，ここで挙げた解析条件は種々の 解析の試みの中から, 実験結果を多少とも再現でき るというものになる.

継手部の解析は接触問題として取り扱う内容と判 断したが, 接触条件である「接触面での力と変位の 連続性」を考虑に入れて計算しようとすると, 本問 題の接触部が同一材料であるために一体化した帯板 の圧縮問題となってしまう. そこで数值解析におい ては，実験の条件を再現できるように，境界条件を いくつかに分類して解析を行い，あとで結果を合成 させる方法をとることにした.

実験条件として, 以下に示す 4 種の条件を設定し た（図一 9 参照）.

条件 1 ほぞ面（ $\Gamma_{1}$ ) にクリアランス があると する. 従って 応力伝達はフラット面 $\left(\Gamma_{2}\right)$ を通し て行われる. 境界条件は端面 $\left(\Gamma_{3}\right)$ に一様圧縮応 力を与え,フラット面 $\left(\Gamma_{2}\right)$ は水平方向 $(x$ 方向) を固定, 垂直方向（y 方向）をフリーとする応力条 件による計算である.

条件 2 条件 1 での計算では，ほぞ面およびほぞ 溝面 $\left(\Gamma_{1}\right)$ の変位を拘束していないため, 結果と して両者の変位はオーバーラップする. そのオーバ 一ラップした変位を半分ずつ元に戻す. 条件 1 の計 算で変形した形状を初期の形状として, フラット面
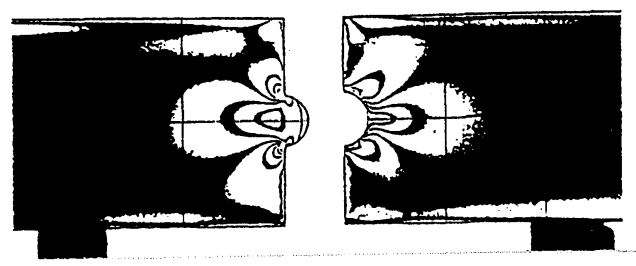

$\mathrm{J}_{\mathrm{A}}-4 \mathrm{R}$
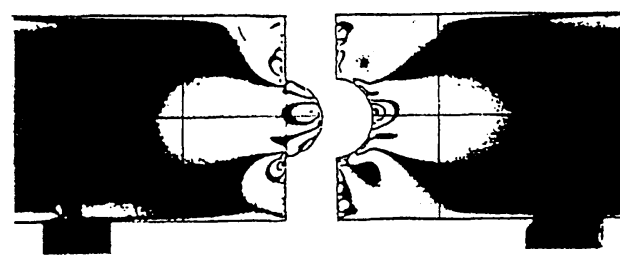

$J_{\Lambda}-6 R$

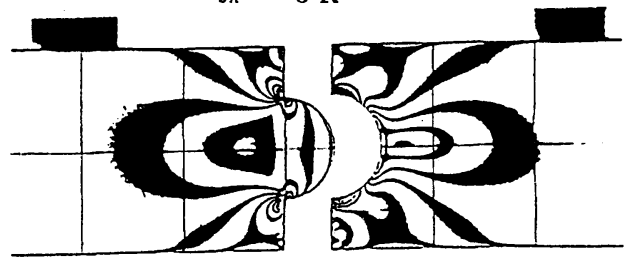

$\mathrm{J}_{\Lambda}-8 \mathrm{R}$

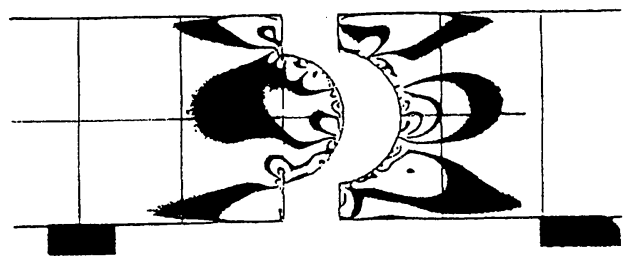

$\mathrm{J}_{\mathrm{A}}-10 \mathrm{R}$

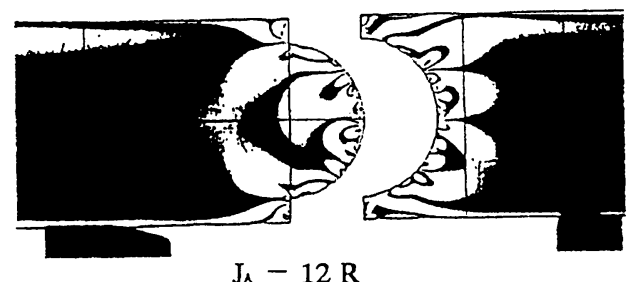

$\mathrm{J}_{\Lambda}-12 \mathrm{R}$
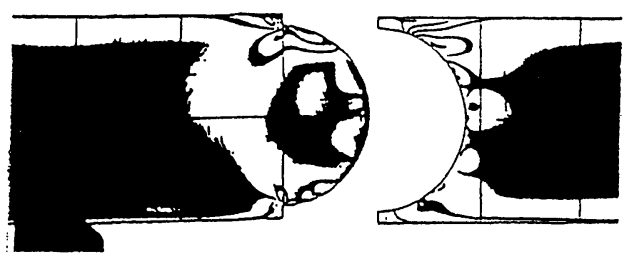

$\mathrm{J}_{\mathrm{A}}-14 \mathrm{R}$

図一8 ほぞ形式継手の二次元光弾性実験

$\left(\Gamma_{2}\right)$ と端面 $\left(\Gamma_{3}\right)$ を $\mathrm{x}$ 方向のみ拘束した変位条 件による計算である. この結果の応力分布を, 条件 1 での応力分布に重ね合わせる.

条件 3 ほぞとほぞ瑇面（ $\Gamma_{1} ）$ のみ接触して お 

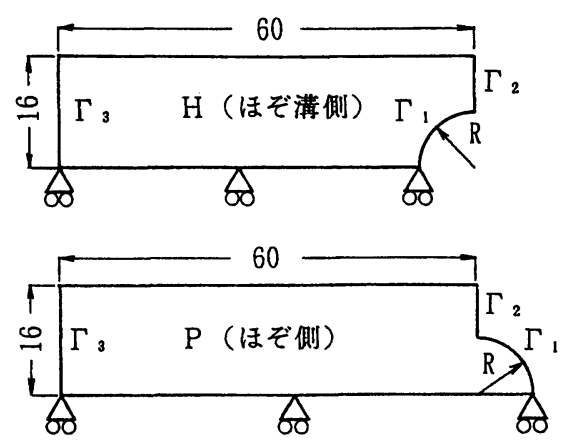

(a) 数値計算モデル
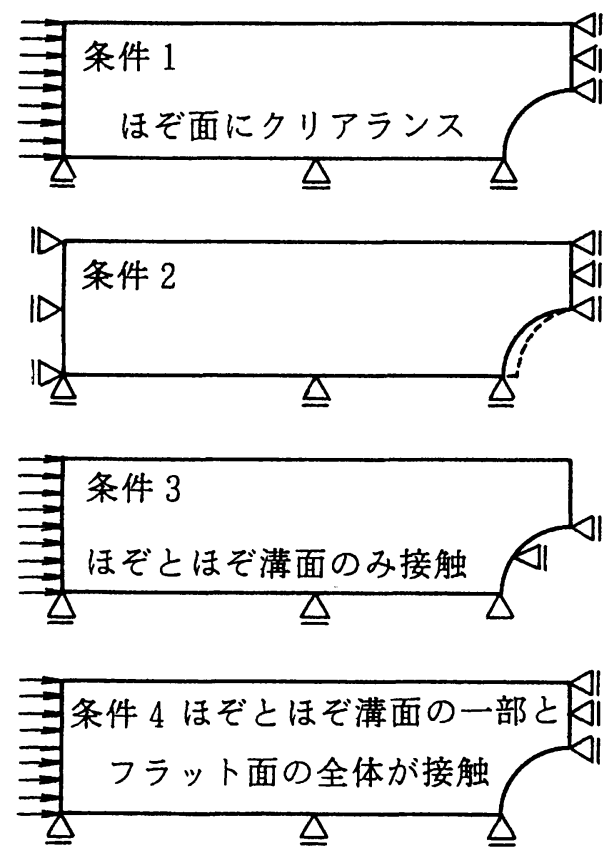

(b) 解析条件の概要

図-9 数值解析モテルと解析条件

り, フラット面 $\left(\Gamma_{2}\right)$ は 接触していないという条 件である. 面 $\Gamma_{1}$ の変位は拘束し, 面 $\Gamma_{2}$ をフリーと し, 端面（ $\Gamma_{3}$ ）に 条件 1 と同じ圧縮応力を与える という条件による計算である.

条件 4 ほぞとほぞ溝面（ $\Gamma_{1} ）$ の一部分と フラ ット面 $\left(\Gamma_{2}\right)$ の 全体が接触しているとするもので あり, 面 $\Gamma_{1}$ の接点一つおきに拘束を与える. 残り の一つおきはフリーとする. 面 $\Gamma_{2}$ はx 方向のみ拘 束. 端面 $\left(\Gamma_{3}\right)$ に条件 1 と同じ圧縮応力を与える という条件による計算である.

図一 10 に各条件による計算結果の一例を示した. 条件 1 の場合は，ほぞとほぞ渪が接触していないの で，ほぞ溝側では丸孔切り欠きを持つ帯板の引張・ 圧縮の場合と同じになる。 $\mathrm{J}_{\mathrm{A}}-4 \mathrm{R}$ から $\mathrm{J}_{\Lambda}-8 \mathrm{R}$ の
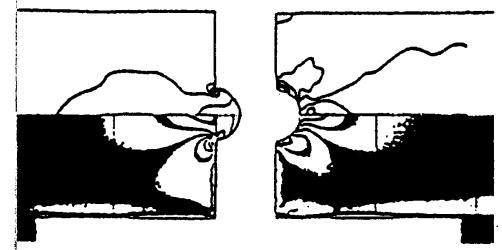

a）条件 1 の場合の結果 $\left(\mathrm{J}_{\mathrm{A}}-4 \mathrm{R}\right)$

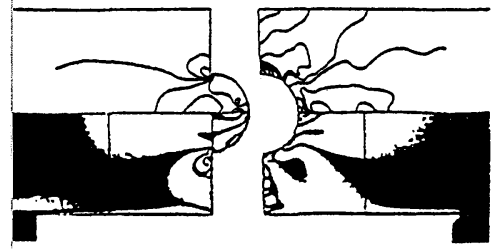

b) 条件 $(1+2)$ の場合の結果 $\left(\mathrm{J}_{\mathrm{A}}-6 \mathrm{R}\right)$

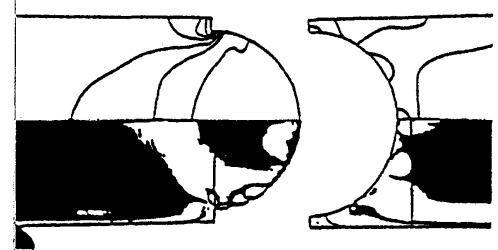

c）条件 3 の場合の結果 $\left(\mathrm{J}_{\mathrm{A}}-14 \mathrm{R}\right)$

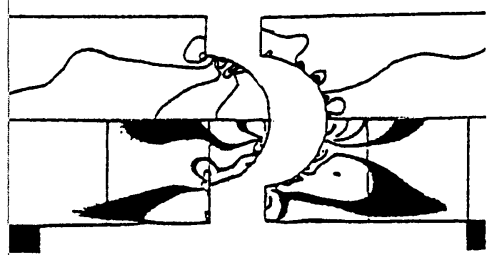

d）条件 4 の場合の結果 ( $\left.\mathrm{J}_{\Lambda}-10 \mathrm{R}\right)$

(上半分が数値計算結果)

図-10 有限要菜法による数值解析

場合の結果がこの場合に近似しているが，ほぞの半 径が小さい場合にはこの境界条件に近くなる.これ はほぞとほぞ溝面（ $\Gamma_{1}$ )がたとえ接触していても， その影響が少なく，フラット面 $\left(\Gamma_{2}\right)$ での応力伝達 が主力となるためと考えられる。図ー10のa）に $\mathrm{J}_{\mathrm{A}}$ - 4R の結果を示した.

条件 1 での計算では，ほぞとほぞ溝面 $\left(\Gamma_{1}\right)$ の変 位を拘束していないため，結果として両者の変位は オーバーラップする. 条件 2 での計算では，これを 変位条件の下で解消させ，両条件下 $\left(\Gamma_{2}\right.$ と $\Gamma_{3}$ が荷 重作用方向に対してのみ拘束される）で得られた応 力分布を重ね合わせたものである.この条件では, 半径が大きくなるとフラット面 ( $\left.\Gamma_{2}\right)$ に大きな応力 が生じ，実験との差が目立つようになる， $\mathrm{J}_{\mathrm{A}}-6 \mathrm{R}$ の結果を図ー10のb）に示した.

条件ー3の場合は，ほぞ・ほぞ溝の半径が大きな 場合に近似する．これは，ほぞとほぞ溝面 $\left(\Gamma_{1}\right)$ を 
通した応力伝達が主力となるためと考えられる、 $\mathrm{J}_{\text {A }}$ - 14 R の結果を図ー10の c) に示した.

条件 4 の場合は, 図ー 8 に示す $\mathrm{J}_{\mathrm{A}}-10 \mathrm{R}$ と, $12 \mathrm{R}$

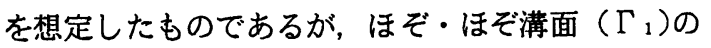
状態は比較的よく再現できている.

以上， 4 種の条件による計算結果を示した. この 中で最む実験結果をよく近似していると思われる図 - 10 の a )とd)について, $\Gamma_{1}, \Gamma_{2}$ 面上の応力 状態を計算値で調べて見ると, 接触面での両者の応 力は一致していなかった. 有限要素法による境界上 の計算値は要素の重心での值であることを考虑して 修正したとしても，ここで取り上げた境界条件だけ ではまだ不十分である. 境界条件の設定見直しや追 加は今後の課題とし，この計算から

(1)実験結果を近似できる境界条件は，ほぞ・ほぞ荆 の半径によって異なる.

(2)数値計算と光弾性実験との組み合わせによる問題 解明は有用である.

などのことが言える. (1)では, 同種類の問題であっ ても, 同一の境界条件による計算処理ができない場 合があることを教えている. (2)では, 数值計算にお ける境界条件の設定の正当性が判断できると同時に, 光弾性実験の結果の正当性の判断む可能となる.

\section{2 つの平面から構成される継手の交角部 における応力性状 '4)，15)}

シールドトンネル覆工は周辺地山からの外力を支 えるとともに，シールド掘進機の推進に利用される から，そのことを踏まえた構造としなければならな い. そこで，突き合わせ平板セグメントモテルによ る基礎的な推力実験を行った ${ }^{15)}$.

セグメントモデルの形状は図ー 11 に示す凸型で ある. 凸型セグメントは $2 つ$ 平面から構成される 交角が継手面に二力所形成されることから，ここに 応力が集中することが予想された.

セグメシトは, シールド掘進機のテール部で組立 られて覆工となる．この時点ではまだ覆工に外力 （土圧）は作用していない。この状態でシールド掘 進機を前進させることになるが，この時のセグメン 卜覆工にはトンネル軸方向の推力が作用しているだ けである. しかし，掘進機の止水および圧力保持の 役目をしているテールシールを通過するところで円 周方向の軸力が生じ，さらにそこを離れると泥水圧 や土圧による応力が発生する．平板セグメントの突 き合わせ実験では, 両者をボルトで固定していない ことから, 両セグメントの応力伝達が不完全となる.

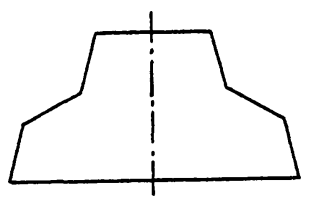

凸型

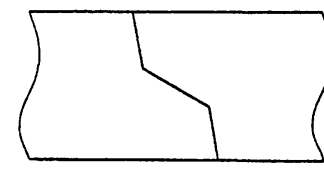

$T t d o$

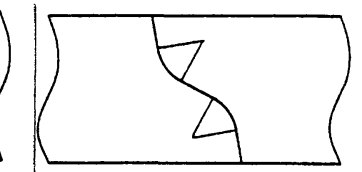

$T t d 6$
図ー 11 凸型セグメントモテルの形状

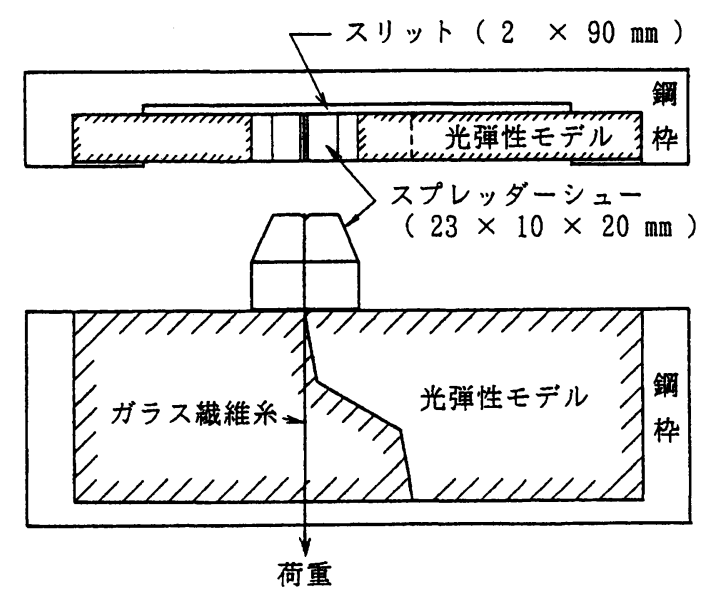

図-12 推力実験概略図

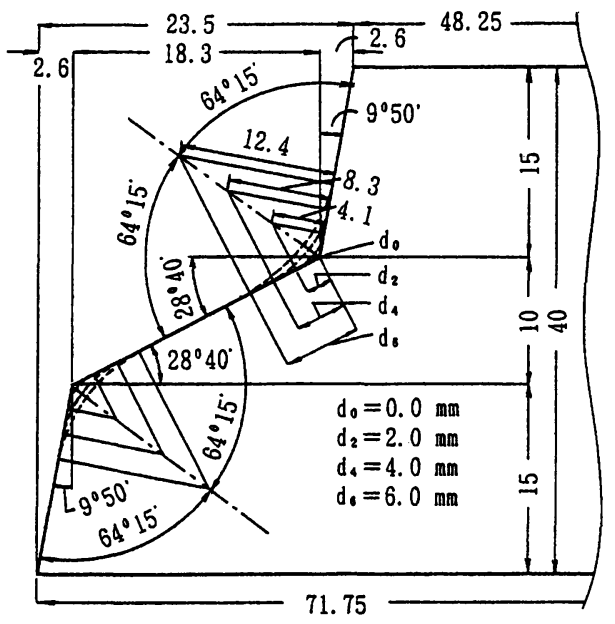

図－13 凸型セグメント凹凸部の詳細

そこで，円周方向に相当する軸力を導入した状態で 実験を行うことにした．軸力はエポキシ樹脂モテル 


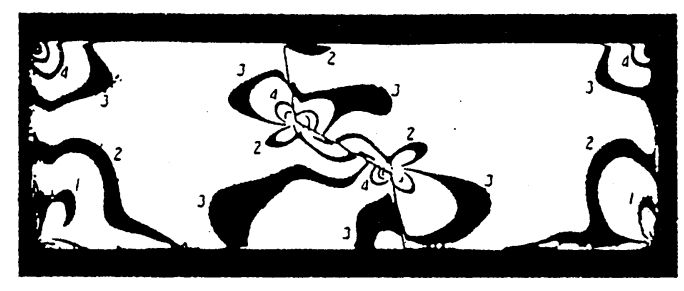

$\mathrm{Tt}_{d 0}-\mathrm{N}$

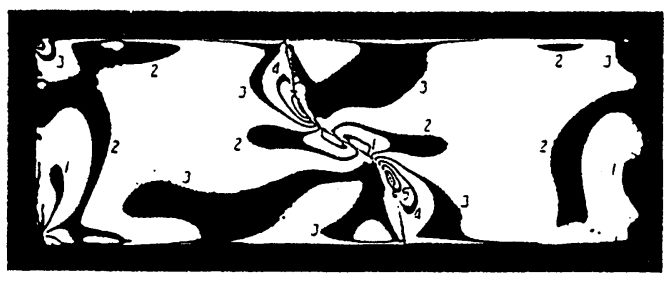

$\mathrm{T} \mathrm{t}_{\mathrm{d} 6}-\mathrm{N}$

図-14 軸力 Nだけが作用している場合の凸型 セグメント突き合わせ部の等色線写真

の線膨脹を拘束することによって導入することがで きるので，実験には応力凍結法を用いた。

図ー1 1 に示すように，凸型セグメントは対称性 を有している. そこで, 対称の位置で切断し，その 一方の上下を入れ替えて突き合わせると長方形にな る. 図-12 に推力実験の概略図を示したが, 両者 を突き合わせたモテルの高さは $40 \mathrm{~mm}$, 幅 $120 \mathrm{~mm}$, 厚さは $9.8 \mathrm{~mm}$ である. このモデルを鋼枠に入れ, トンネル軸方向からスプレッダーシューを介して推 力を作用させ，その状態で応力凍結を行うと軸力を 導入した推力実験が行える.

図ー12 の鋼枠に矩形セグメントをセットし，負 荷を与えないで㐫力凍結実験を行うと, 軸力だけが 作用している場合の等色線が得られる.この実験に よる平均の縞次数は 2.3 次であった. 縞次数亡応力 の関係は $\mathrm{n}=\alpha \times \sigma \times \mathrm{t}$ （ $\mathrm{n}$ : 縞次数, $\alpha$ : 光弾性 感度, $t$ : モデの厚さ) で与えられているから, 軸力 $\mathrm{N}$ は $\alpha=4.0 \mathrm{~cm} / \mathrm{kgf}(0.408 \mathrm{~cm} / \mathrm{N}), \mathrm{h}=4.0$ $\mathrm{cm}, \mathrm{t}=0.98 \mathrm{~cm}$ として $2.3 \mathrm{kgf}(22.5 \mathrm{~N})$ を得る.

図一 14 に一例として, 凸型セグメント乫き合わ せモテルに軸力だけを作用させた場合の等色線写真 を示した.ここに記号 $\mathrm{T} \mathrm{t}$ の後の添え字は, セグメ ント接触面の形状変化を, 凹凸の最深部または最先 端からの距離を示している.』0は凹部または凸部が 直線の交点であることを示し，。6は交点からの距離 が両側に $6 \mathrm{~mm}$ で, この位置に立てた両垂線との距 離 $12.4 \mathrm{~mm}$ を半径とする円弧となっていることを表 している（図一１３参照）。なお, 実験モデルの形 状寸法は, 光弾性実験と並行して行われた実物モテ
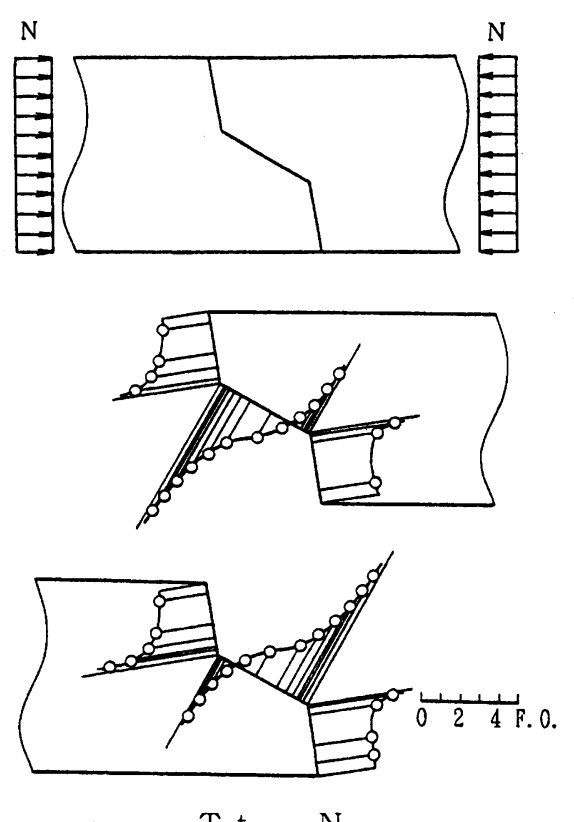

$T t_{d 0}-N$
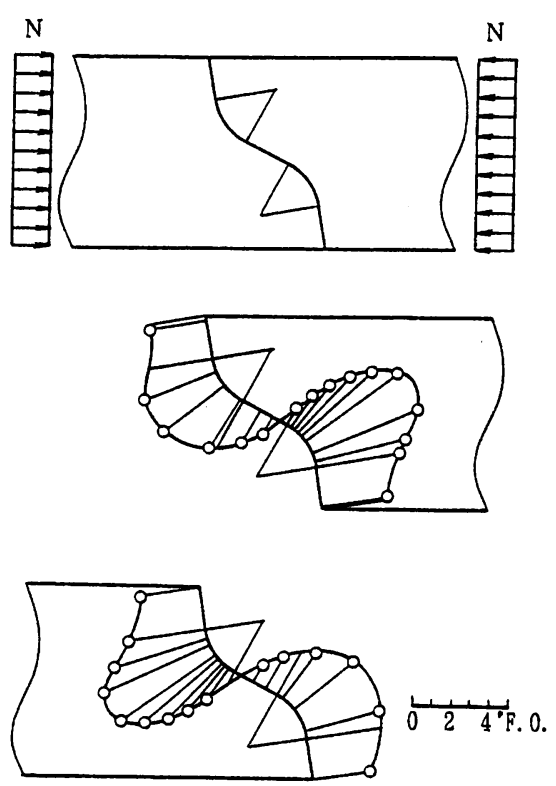

$T t_{d 6}-N$

図ー15 軸力Nだけが作用している場合の凸型 セグメント接触位置の等色線写真

ルの形状を参考にしている ${ }^{3)}$ ，4).

凸型セグメント継手部の応力集中の度合いは, 継 手角度によって異なると考えられる. 必要に応じ, 実験で確かめることが望ましい.

図-15に図-14に関わる接触位置の縞次数分 布を示したが，凹凸部が直線の交点となっていると 


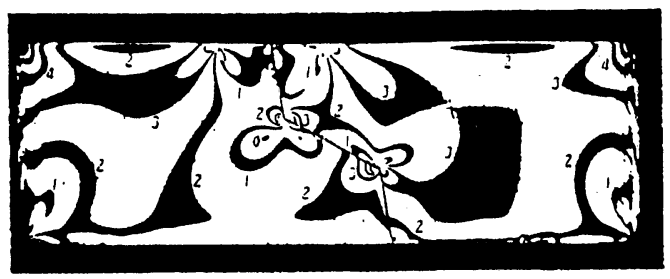

$T t_{d o}-J-N P$
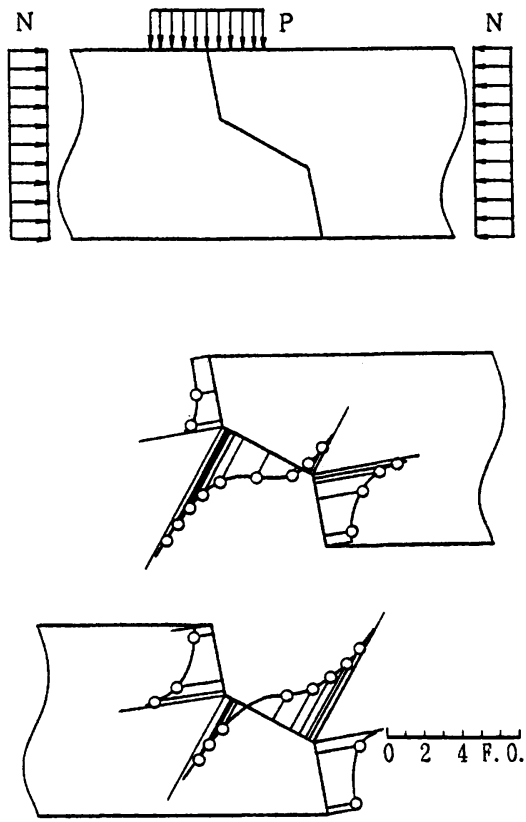

$T_{d_{0}}-J-N P$

図-16 軸力 $\mathrm{N}$ と推力 $\mathrm{P}$ が作用している場合の凸型セ グメント乫き合わせ部の等色線写真と接触位 置の縞次数分布

ころに大きな応力集中が生じていることが分かる． これに対し，凹凸部の形状を円弧としたものでは， 応力集中もなく，よい応力分布となっている。なお, 接触面は自由周辺ではないから，厳密な意味での主 応力ではないことに注意する必要がある.

図一1 6 は，軸力を導入するとともに，推力 $P$ を 作用させた実験の等色線写真亡接触位置の縞次数分 布である.この場合の推力位置は, 両セグメント接 触部の上端にスプレッダーシューの中心が合ってい る場合である. 推力荷重は $\mathrm{P}=2.03 \mathrm{kgf}(19.9 \mathrm{~N})$ で である.なお，反力は鋼枠の下面全体で受けている.

図-16の結果を, 図-15のT $t_{d 0}-\mathrm{N}$ と比較 して見ると，凹部応力の減少が見られる．これは， 凹部がリング方向軸力Nによって広げられるが, 卜 ンネル軸方向軸力 $\mathrm{P}$ によって押し戻されるからであ
る. 凹部は押し広げによる応力集中が生じ，クラッ クの発生も考えられるので，その部を円弧にするな どの処置が必要である.なお, 凹部の応力集中の度 合いは, 軸力と推力のバランスによって決まるので 使用するセグメントでその関係を調查しておくこと が望まれる.

図一16 1 1 個のジャッキによる推力が継手部に 作用している場合であるが, 矩形, 台形の場合も最 小単位の推力が作用する場合を取り上げた.これは, 実験結果を組み合わせることにより, 複数の推力が 作用している場合の推定ができると判断したことに よる.

\section{5. せん断キーを有する継手部の応力性状}

土木学会発行のトンネル標準示方書によれば ${ }^{16)}$ セグメントリングの構造モデルを, セグメント継手 の力学的な取り扱いの相違によって, (1) 剛性一様 セグメントリング，(2) 多ヒンジ系セグメントリン グ，(3) 回転ばねを持つセグメントリング，に分類 している.ここで(3)の計算法は, リング継手のせん 断剛性の大きさによって千鳥組による添接効果が表 現できることから，セグメントリング耐荷機構を説 明できる有効な一方法であると言われている，せん 断剛性による曲げモーメントの伝達を図れる構造の 一つとして，せん断キ一を持つ継手部が考えられる. ここでは, 台形状のせん断キ一を継手部に設けた場 合の応力伝達や応力集中について取り上げる ${ }^{17)}$.

図一 17 は, せん断キ一試験モデルの形状寸法で ある. 円形トンネルの一部を模したものであるが, 実験の都合上，長方形平板突き合わせとした．また， キ一溝に止水溝の役目む付与しようという考えから, キーとキー湿の形状は台形とし, 底部にシール材を 貼ることを想定した.

図一１８にせん断キ一試験の概略を示したが， 3 個のセグメントモデルは, 組み立てられて鋼枠にセ ットされる．鋼枠を用いたのは, トンネル円周方向 からの軸力を導入するためである. 軸力はエポキシ 樹脂の線膨張を拘束することによって導入できるの で，実験には応力凍結法を用いた。

図ー17において, (4), (5)，(8)の組み合わせモデ ルは, キー溝がセグメント高さの中央に位置してい る場合, (6)，(7)，(9)モデルは端に㟢っている場合で ある. (4)，(6)モデルにはキ一溝，(5)，(7)はキー，(8)， (9は左側にキ一，右側にキ一溝が加工されている.

キーの寸法は、対辺の一方が $6.54 \mathrm{~mm}$, 他方が $10 \mathrm{~mm}$, 高さが $3 \mathrm{~mm}$ の等脚台形 (侠角 : $60^{\circ}$ ) 

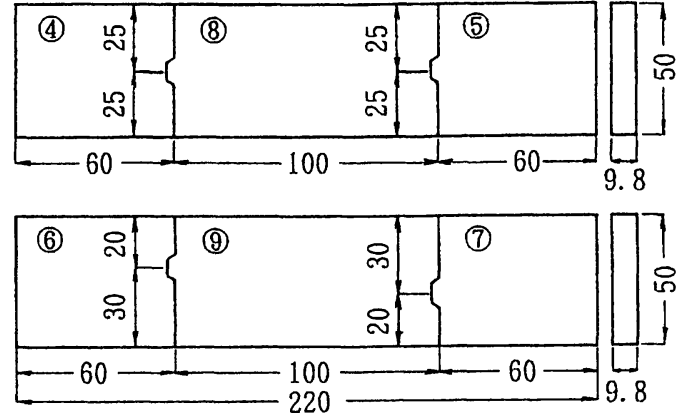

図-17 せん断キー試験モテルの形状寸法

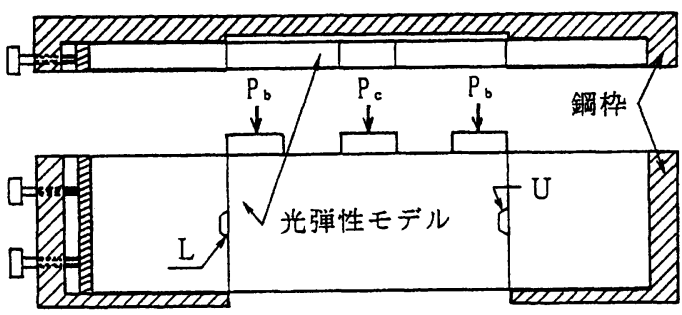

図一１８４ん断キー試験の概略図

である. キー溝はキーに合わせて加工した. 図ー1 8 にせん断キ一試験の概略図を示したが，モデル(4) と(5)および(6)と(7)は下辺が全断面で支えられている. これに対し，(8)と(9)の下辺は支えられていない．外 力はセグメントの厚さ方向から作用させる.

せん断キ一試験のモテルとして，図一17のよう な組み合わせモテルにしたのは，(8)と(4)，(8)と(5)の 間に相互干涉が生じないことから，2 種類の実験内 容を含ませたことによる. (4)，(8)，(5)の組み合わせ モデルにおいて，(8)左側のキ一は，(4)キ一溝の下端 で接触するが, (8)右側のキー溝は(5)上端のキーに接 触する. (6)，(7)，(9)モデルの場合も同様である.

実験は図一18 に示す鋼枠にモテルを㨂入し，左 側のねじで均等に締め付け, その状態で応力凍結を 行った. この実験装置で導入される軸力 $N_{1}$ は, 縞 次数で 2 次である.

表ー 2 に実験の種類を示した. 記号に用いたアル ファベット文字で, $\mathrm{Q}$ はせん断力, $\mathrm{P}$ とHはキーとキ 一淟をピン・ホゾになぞらえた表現、LとUはキ一 またはキ一溝の下と上という意味である（図一18 参照).

図一19にキーおよびキー溝近傍の等色線写真の 一例を示した. 図一19の上段は軸力だけが作用し ている場合，中段は図-17 に示す(8)，(9)モデルの 中央に荷重を作用させた場合，下段は(8)，(9)モテル

\begin{tabular}{|c|c|c|c|}
\hline 記 & $d_{m m}$ & $P \circ 1(N)$ & $P_{b_{1}}(\mathrm{~N})$ \\
\hline$Q_{25} P-N_{1}$ & 25 & 0.0 & 0.0 \\
\hline$Q_{25} P L-N_{1}-P_{01}$ & 25 & 19.9 & 0.0 \\
\hline$Q_{25} P L-N_{1}-P_{b_{1}}$ & 25 & 0.0 & 10.1 \\
\hline$Q_{25} \mathrm{H}-\mathrm{N}_{1}$ & 25 & 0.0 & 0.0 \\
\hline$Q_{23} H U-N_{1}-P_{01}$ & 25 & 19.9 & 0.0 \\
\hline$Q_{25} \mathrm{HU}-\mathrm{N}_{1}-\mathrm{P}_{b_{1}}$ & 25 & 0.0 & 10.1 \\
\hline$Q_{20} P-N_{2}$ & 20 & 0.0 & 0.0 \\
\hline$Q_{20} P L-N_{1}-P_{01}$ & 20 & 19.9 & 0.0 \\
\hline$Q_{2} \circ P L-N_{1}-P_{b_{1}}$ & 20 & 0.0 & 10.1 \\
\hline Qso $H \quad-N_{1}$ & 30 & 0.0 & 0.0 \\
\hline$Q$ s。 $\mathrm{HU}-\mathrm{N}_{1}-\mathrm{P}_{\circ 1}$ & 30 & 19.9 & 0.0 \\
\hline$Q_{30} H U-N_{1}-P_{b_{1}}$ & 30 & 0.0 & 10.1 \\
\hline
\end{tabular}

$\mathrm{d}$ : モデル上端からキー, キー漊中心位膡ま での距離, $\mathrm{N}_{1}$ : 軸力, モデルの厚さ $\mathrm{t}=9.8 \mathrm{~mm}$
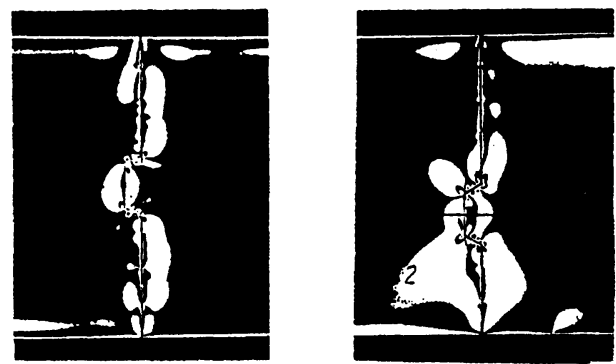

$Q_{25} \mathrm{P}-\mathrm{N}_{1}$

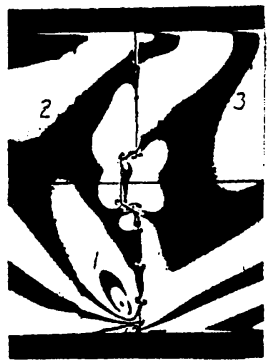

$Q_{25} P_{L}-N_{1}-P_{c 1}$

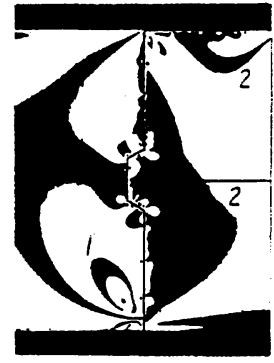

$\mathrm{Q}_{25} \mathrm{PL}-\mathrm{N}_{1}-\mathrm{P}_{01}$

図ー19 せん断キ一せん断試験の等色線写真 


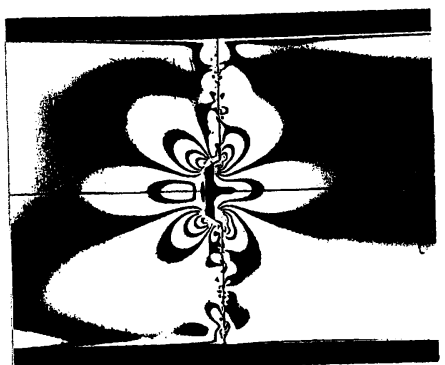

（a）軸力 $\mathrm{N}_{1}$ のみが作用している場合

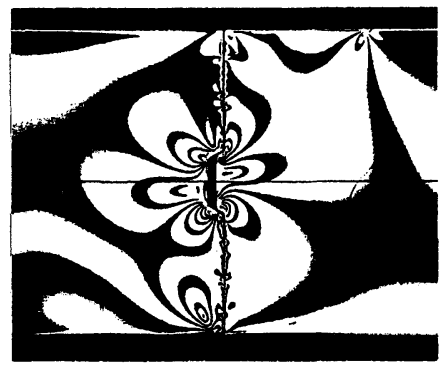

（b）軸力 $\mathrm{N}_{1}$ とせん断力 $\mathrm{P}$ が作用している場合 图ー20 シール溝を設けたせん断キーせん断試験 の等色線写真

の左端，右端に荷重が載っている場合である，載荷 は鋼製のスプレッダーシュー（23×10×20 mm） を介して行った. 載荷重 $\mathrm{P} 。 1$ は $\mathrm{P}$ 。1 のほぼ半分とな っているので, 図一19の中段とそれに対応する下 段接触位置の縞模様は計算上一致することになる.

図ー19の中段と下段の実験では，応力がキーま たはキー溝をどのように経由して伝達すか, またど の部分に集中するかを調べるのが目的である. しか し, この等色線写真のキーまたはキ一溝接触部を含 む近傍の応力に際だった変化を見ることができない． 強いていえば，せん断力が作用しているキーとそれ に接触するキー溝では，キー瑇に力が集中している. 一方, せん断力が作用しているキ一溝がキーの上側 で接触する場合にはキー溝上側に力が集中する.こ れらのことは, 力の伝達を考えると理解できること であるが, この様子が実験写真には顕著に表れてい ない.これは, キーとキ一瑇の組み合わせに無理が なく，両者が一体となって挙動しているからである と思われる. このことから, キーとキー溝のクリア ランスは可能な限り小さくすることが望ましい，ま た, この部の応力集中については, キーの隅よりも キー溝隅の方が大きくなる傾向にある.これはキ一 荆隅の押し広げ, すなわち斜め引っ張りせん断が働 いていることを意味している，したがって，破壊は この隅から始まるので，この部の応力集中を軽減す
るような形状にしておく必要がある.

図一20は，ほぞ溝にシール材を貼付する場合を 想定し，ほぞの先端を少し切り取って行ったせん断 試験の等色線写真である. 図の（a）は軸力 $\mathrm{N}_{1}$ のみ が作用している場合，（b）は軸力 $N_{1}$ とせん断力 $\mathrm{P}$ が作用している場合で，（a）は図一19の Q ${ }_{25} \mathrm{P}$ $-\mathrm{N}_{1}$ ，（b）は Q ${ }_{25} \mathrm{PL}-\mathrm{N}_{1}-\mathrm{P}_{b_{1}}$ 之全く同じ条件 の実験である.

図ー 19 と図一 20 の両者を比較してみると, 僅かな空隙を設けた後者のほぞとほぞ满の接触部に 大きな応力集中が生じていることがわかる.これら の応力集中は局部的なものではあるが，これがせん 断破壊の引き金となることも考えられる.このこと からも, キ一溝に止水溝の役目を付与することは好 ましくない. キ一溝接触部の応力伝達は, ほぞとほ ぞ溝が一体となって挙動するような状態が望ましく， それには寸法精度の高い製品を用いることである.

\section{6. 結論}

本論文は，セグメント間継手部の応力伝達に関す る基礎的な調査を, 光弾性実験で行ったものをとり まटめたものである.この実験では, 応力の分布を 視覚で捉えることができるので, 応力伝達を調査す るのに適した手法といえる. しかし，セグメント間 は接触問題であることから，これらの応力性状を正 確に把握することは容易でない，そこで, 単純なモ デルによる基礎的な実験之計算も取り入れ, 継手部 の応力性状を検討した．その結果

1 ）台形継手はリング方向への応力の伝達領域が広 がることにより, 応力伝達は良好となる7). しか し，トンネル軸方向に対する継手角度が大きくな るにつれて, 鋭角部の応力に乱れが生じるので, ほどよい継手角度の選定が必要である。

2) ほぞ形式継手の場合, ほぞ・ほぞ溝の径が小さ い場合の応力伝達は継手面で伝達され, 径が大き くなるとほぞと継手面の両方で行われる. ほぞの 径を必要以上に大きくすると継手平面部に応力が 集中し, その部の破損の原因となる. ほぞの径は 必要最小限の大きさとすることが望ましい.

3) 光弾性実験法之有限要素法などの数値解析法を 併用することは, 接触問題を含む局部応力の状況 を把握するのに有効である.

4) 凸型セグメントの場合のように，凹凸部の先端 を直線で交差させると応力集中が発生する. ジャ ッキ推力の影響を含めて, 応力集中の影響を検討 する必要がある. 
5 ）せん断キーを持つセグメント継手では，キーと キ一溝を可能な限り密着させ, 両者が一体となっ て挙動するような状態にすることが望ましい．ま た, キ一溝隅には斜め引っ張りせん断による応力 集中が発生するので，この隅の応力集中を軽減す るような形状にしておく必要がある.

6 ）セグメントは梁などにモテル化する構造材とし ての設計をするが，セグメントの形状，ほぞなど の細部構造によっては，応力集中を発生する場合 もあるので，局部的な応力分布に留意する必要が ある.

などのことを明らかにすることができ，継手部の応 力は複雑であり, 局部的な応力を考慮し, 細部構造 を合理的なむのにする必要があることを示した.

セグメント継手部については，トンネル標準示方 書（シールド工法編）・同解説 ${ }^{18)}$ の第 7 章セグメ ントの設計細目第 56 条で言及している（：セグメ ントの継手構造は, 必要な強度を有するとともに, 組立の確実性，作業性および止水性を考慮して定め るものとする）。これによれば継手部の応力性状は 必要な強度を有するという文言に包含されることに なる。

セグメントは必要な強度に加え，施工性や止水性 を兼ね備えなければならないから，セグメントの開 発は過去の経験を踏まえ, 試行錯誤を繰り返しなが ら設計を試みることになる．そして強度的には設計 荷重に耐えうるものを目標とするが，シールドトン ネルの機械化施工が一般的となった現在，それに用 いるセグメントは，強度に加え施工性と経済性に優 れているものでなければならない.このようなこと から，種々のセグメントが考案されているが，その 形状は複雑化する傾向にある。

筆者らはこうした現状を踏まえ，セグメントの開 発が経験と試行錯誤に頼るだけでなく，継手部の応 力性状を踏まえた合理的なセグメントとして開発さ れることを期待し，継手部の実験的解明に取り組ん だ. セグメント継手部は，矩形セグメントに代表さ れるように，基本的には突き合わせ構造であること から，接触問題を含むことになる．このため，形状 によっては応力が集中し, 接触応力とあわせて複雑 な応力状態となる．セグメント継手部に限らず，組 立による構造物は個々の部材の寸法精度が重要な要 素となる，一方，寸法精度を上げることは製作費の 增に綮がることであり，継手の細部構造が与える影 響を十分検討して合理的なものとする必要がある.

なお，この実験で得られた一連の資料は，有限要 素法などによる計算と対応させ, 普遍性のある資料 としてまとめて行きたいと考えている。
謝辞：本研究を行うにあたって小山工業高等専門 学校の橋本彰三教授ならびに山下進講師にご助力を 頂いた．記して感謝の意を表する次第である.

\section{付 録}

本論文で用いた光弾性実験法に関する用語につい て略記する。

○光弾性実験法 : 偏光の性質を利用し, 透明体で 作ったモデを用いて，外力をになう構造物の内部 に起こる内力を測定する実験的な方法. 内部の応力 状態が等高線のような縞模様で表現できることから 応力の流れと大きさを視覚で捉えることができる.

○応力凍結法 : 光弾性実験材料（一般にエポキシ 樹脂）モテルを実験炉にセットし，温度を $130{ }^{\circ} \mathrm{C}$ 前 後まで上げ，負荷を与えて徐冷すると変形が固定す る. 負荷を取り去っても変形が固定されていること から，この状態を光弾性装置で観測することにより 内部の応力状態を知ることができる.この方法は主 として三次元光弾性モデルに適用するが，二次元モ デルに適用してもよい。

等色線：光弾性実験装置を用いて得られる縞模 様は主応力差 $\left(\sigma_{1}-\sigma_{2}\right)$ 一定の軌跡である. 縞模 様に色がついていることから等色線亡呼称している この縞模様を写真で撮影したものが等色線写真であ る.

$\bigcirc$ 縞次数：偏光子（偏光を得る光学装置）之偏 （検）光子の間に置かれたモデルに力を加え，それ を徐徐に增して行くと位相差も増し, 偏光の強さが 0 から始まって明暗交互に変化する．視野が暗黒と なる順番を消光次数または縞次数という。

○暗視野：偏光子亡偏（検）光子を直交させると， その視野は暗くなり，このとき得られる縞は，0次， 1 次， 2 次，・・立なる。このような光学系を暗 視野という.

○明視野：暗視野の光学系において，偏（検）光 子を $90^{\circ}$ 回転すると明視野の光学系になる.この とき得られる編は 0.5 次, 1.5 次, 2.5 次 ・ ・ と なり，単独むしくは暗視野で得られる縞模様に，図 上で重ねて利用することができる.

\section{参考文献}

1）山本稔，森 麟，相馬誠人：六角セグメント現場を視 察して一中華人民共和国引台入泰灌溉用水路一， 卜 ンネルと地下，第 24 巻 3 号，pp.35－42，1993 年.

2）都甲博二，荒川婜治，寺崎勝，大関宗孝：わが国初の の六角形セグメントの開発，土木学会誌, vol.78， pp.17-19, 1993-4. 
3）山崎宏, 今田徹, 山崎良一, 三戸夢二 : ウィング (凸型) セグメント実物大載荷試験（その 3 ） - せ ん断キーせん断試験 一, 土木学会第 52 回年次学術 講演会講演概要集 III-B 121, pp.242-243, 1997 年 9 月.

4）三戸㥶二, 今田徹, 山崎良一, 山崎宏 : ウィング (凸型) セグメント実物大載荷試験（その 4) - 軸 力導入継手曲げ試験 一, 土木学会第 52 回年次学術 講演会講演概要集 III-B 122, pp.244 - 245, 1997 年 9月.

5）今田徹, 山崎良一, 野本寿, 三戸愳二 : 矩形セグメ ント継手の応力性状に関する光弾性実験的研究，土 学会論文集 No.588/VI-38, pp.51-60, 1998. 3.

6）今田徹, 山崎良一, 野本寿 : 台形セグメント継手の 力学特性について, 土木学会第 48 回年次学術講演会 講演概要集 III - 11, pp.76-77, 1993 年 9 月.

7）今田徹, 山崎良一, 野本寿, 三戸憲二：台形セグメ ント継手の力学特性について (2), 土木学会第 49 回年次学術講演会講演概要集 III-608, pp.1206 - 1207,1994 年 9 月.

8）今田徹, 三戸㥶二, 山崎良一, 野本寿 : 台形セグメ ントの開発一台形セグメント載荷曲げ試験結果につ いて一土木学会第 49 回年次学術講演会講演概要集 III-609, pp.1208 - 1209, 1994 年 9 月.

9）平出亨, 福島昭男 : ホゾ付きセグメントの性能確認 試験，トンネルと地下, 第 25 巻 10 号 , pp.21 - 32, $1993-10$.

10）山崎良一, 今田徹, 三戸憲二, 橋本彰三：シール
ドトンネル覆工応力について(2), 日本光弾性学会第 17 回研究発表会講演論文集, pp.117 - 120, No.17 (1995).

11）橋本彰三, 山下進, 山崎良一 : シールドトンネル覆 エセグメント継手部の応力解析, 日本光弾性学会第

18 回研究発表会講演論文集, pp.95-98, No.18 (1996).

12）橋本彰三, 山下進, 山崎良一 : シー ルドトンネル覆 エセグメント継手部の応力解析 II, 日本光弾性学会 第 19 回研究発表会講演論文集, pp.141 - 144 ,

No.19 (1997).

13）西田正孝：材料力学 光弾性で補説する, 森北出版社, p.298, 1977.

14）土木学会：トンネル標準示方書（シールド工法編）

・同解説, 土木学会, pp.131-134，1996年 7 月.

15）山崎良一, 今田徹, 野本寿, 三戸憲二, 山崎宏 : シ 一 ルドトンネル覆工応力について（5）, 日本光弾性 学会第 19 回研究発表会講演論文集， pp.137-140, No.19 (1997).

16）土木学会：トンネル標準示方畫（シールド工法編）

・同解説, 土木学会, pp.76-81，1996年 7 月.

17）山崎良一, 今田徹, 野本寿, 三戸熹二, 山崎宏 : シ ールドトンネル覆工応力について（6）, 日本光弾性 学会第 20 回研究発表会講演論文集, pp.131- 134, No.20 (1998).

18）土木学会 : トンネル標準示方書（シールド工法編）

・同解説, 土木学会, pp.90-91，1996 年 7 月.

\title{
LOCAL STRESS AT SEGMENT JOINTS OF SHIELD TUNNEL LINING
}

\author{
Toru KONDA, Ryoichi YAMAZAKI, Toshi NOMOTO, Kenji MITO \\ and Hiroshi YAMAZAKI
}

\begin{abstract}
Although various types of segments and segment joints are employed, most segment joints are butt type joints with flat face or tongue and groove. Therefore, the forces in the lining are transferred through contact face at the joint. The force transfer at the contacted surface is very complicated phenomenon and may produce local high stress concentration. The local stress at segment joint of basic types segments such as rectangular or trapezoidal shape under various forces is investigated by photo-elastic method. The results show that smooth stress transfer can be obtained but high stress may develop in local area which should be considered in design.
\end{abstract}

